Planta Medica

Volume 54, Issue 2, 1988, Pages 109-111 Received: December 8, 1986

\title{
Decrease in plasma cholesterol, triglycerides and CPK levels in rats fed on the marine microalga Dunaliella tertiolecta
}

Jaime Fabregas ${ }^{1,4}$, Concepción Herrero ${ }^{1}$, Manuel Parafita ${ }^{2}, \mathrm{~J}$ Paz ${ }^{3}$, Buenaventura Cabezas $^{1}$, Julio Abalde ${ }^{1}$

${ }^{1}$ Departamento de Microbiología y Parasitología, Universidad de Santiago, Santiago de Compostela, La Coruña, Spain.

${ }^{2}$ Departamento de Fisiología, Universidad de Santiago, Santiago de Compostela, La Coruña, Spain.

${ }^{3}$ Hospital General de Galicia, Universidad de Santiago, Santiago de Compostela, La Coruña, Spain.

Fabregas J, Herrero C, Parafita M, Paz JM, Cabezas B, Abalde J. Decrease in plasma cholesterol, triglycerides and CPK levels in rats fed on the marine microalga dunaliella tertiolecta. Planta Med 1988;54(2):109-11.

DOI http://dx.doi.org/10.1055/s-2006-962362

Abstract: The dried marine microalga Dunaliella tertiolecta was fed to weaning albino rats for 12 days as the sole protein source at a protein level of $12 \%$ protein from casein. Plasma cholesterol, triglycerides, and CPK levels were significantly lower in animals given the microalgal diet than in the control group with values $19.12 \%$, $45.80 \%$, and $43.90 \%$ lower, respectively. These results suggest that the marine microalga Dunaliella tertiolecta has potential application as a hypocholesterolemic or hypolipidemic agent.

\section{Introduction}

There are numerous reports on the hypocholesterolemic properties of a variety of materials derived from biological sources and foods (1) but the hypocholesterolemic properties of microorganisms are less well known. Hypocholestero1emic substances 
have been found in fungi such Penicillium (2) , Monascus species (3), Aspergillus terreus (4), and Fusarium graminearum (5).

In trials involving the feeding of weaning rats with freshwater micro algae, it was observed that the serum cholesterol levels were lower in animals given the microalgal diets than in controls fed on a casein-based standard diet. This hypocholesterolemic effect increased as the percentage of microalgae in the diet increased $(6,7,8,9)$. This cholesterol lowering property has not been observed in marine microalgae.

In the present paper, we show the decrease in the plasma cholesterol, triglycerides, and CPK (creatine phosphokinase) of weaning albino rats fed on the marine microalga Dunaliella tertiolecta.

\section{Materials and Methods}

Dunaliella tertiolecta (Chlorophyceae) was obtained from The Culture Centre of Algae and Protozoa, Cambridge, England, and was cultured under conditions previously described (10). The cells were collected by centrifugation at the end of the logarithmic phase and dried in an oven at $60^{\circ} \mathrm{C}$ for $24-30 \mathrm{~h}$.

In the test diet, the marine microalga Dunaliella tertiolecta was the sole source of protein. Casein was the protein source in the control diet. The standard AOAC (11) procedure was used for protein analysis and the protein contents of the feeds were calculated as $\mathrm{N} \times 6.25$. Taking into account the nutritional requirements of the rats $(12$, 13) and the protein content and amino acid profile of $D$. tertiolecta (14), the diets were formulated using a linear programme operated on Hewlett Packard HP 9817 Computer. The formulae of the control and microalgal diets are shown in Table 1.

Female Wistar weaning rats weigh 40-48 g were randomly divided into two groups of ten. The rats were caged individually, and food and water were given ab libitum.

The rats were maintained at $25^{\circ} \mathrm{C}$ and subjected to alternating $12 \mathrm{~h}$ periods of light and darkness. The animals were given the test diets for 12 days and food consumption was measured daily. At the end of this period, the individual body weights were recorded and blood was collected for serum determinations.

The plasma obtained by centrifugation of total blood was analyzed for cholesterol, triglycerides, and CPK using an automatic analyzer (HITACHI 737). 


\begin{tabular}{|c|c|c|}
\hline \multirow[b]{2}{*}{ Component } & \multicolumn{2}{|c|}{ Level of component ( $\mathrm{g} / \mathrm{kg}$ diet) } \\
\hline & Control diet* & Microalgal diet* \\
\hline Casein $+0.5 \%$ Methionine & 150 & - \\
\hline Alga $+0.3 \%$ Methionine & - & 253 \\
\hline Cellulose & 40 & 38 \\
\hline Oil & 80 & 54 \\
\hline Mineral mixture ${ }^{* *}$ & 50 & - \\
\hline Vitamin mixture ${ }^{\star * *}$ & 50 & - \\
\hline Sucrose + corn starch $(1: 1)$ & 630 & 655 \\
\hline \multicolumn{3}{|c|}{ 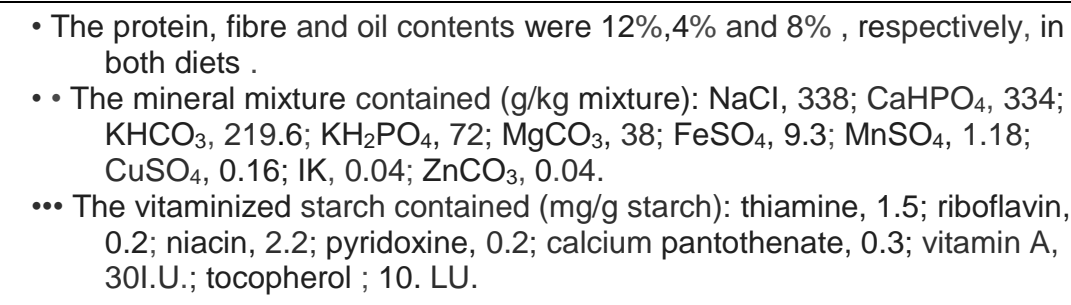 } \\
\hline
\end{tabular}

\section{Results and Discussions}

The test diet with $25 \%$ of dried $D$. tertiolecta supplies $12 \%$ of protein in the feed, which covers the requirements of the weaning rats. The amino acid profile of $D$. tertiolecta covers the amino acids requirements of the rat except for methionine (14, Planta medica 1988 12, 13) and, therefore, the microalgal diet was supplemented with $0.3 \%$ of methionine. In this way, the essential amino acids requirement of the rats are covered. The control diet is supplemented with $0.5 \%$ of methionine because casein is deficient in this amino acid. Both diets were adjusted a t $4 \%$ of crude fibre and $8 \%$ of oil by appropriate additions of cellulose and olive oil.

The analysis of minerals (15) of the microalga and the adjustment by linear programmation according to the requirements of the rat $(12,16,17)$ indicate that the dried microalga.at a $25 \%$ level in the diet covers all these requirements. Therefore, mineral mixture was not added to microalgal diet. If we added mineral salts, diarrhea was produced in the rats, probably due to a high increase in the salts proportions in the feed by the sum of the salts added and the salts provided by the marine microalga.

There were very good food intakes in both control and test rats, suggesting that the results of this study cannot be ascribed to decreased feed intake during the 
experimental period. The intake of food and drink was similar in both groups and theweight gained at the end of the assay was $49.57 \pm 5.12 \mathrm{~g}$ for the rats fed on the control diet and $39.10 \pm 5.65 \mathrm{~g}$ for the rats fed on $D$. tertiolecta.

A non-parametric test of Mann-Witney-Wilcoxon indicates a significant $(p<0.01)$ decrease in the plasma cholesterol, triglycerides, and CPK levels in rats fed on $D$. tertiolecta as compared to rats fed on control diet of casein (Table 11). The levels of cholesterol, triglycerides. and CPK in plasma of rats fed on $D$. tertiolecta were $19.20 \%$, $45.80 \%$ and $43.90 \%$, respectively, lower than in plasma of rats fed on the control diet of casein.

Table II. Plasma cholesterol, triglycerides and CPK levels in rats fed on control diet of casein and algal diet of $\mathrm{D}$. tertiolecta.

\begin{tabular}{lcc}
\hline & Control diet & Microalgal diet \\
\hline Cholesterol $(\mathrm{mg} / 100 \mathrm{ml})$ & $85.66 \pm 8.73$ & $69.20 \pm 4.81$ \\
Triglycerides $(\mathrm{mg} / 100 \mathrm{ml})$ & $69.25 \pm 5.61$ & $37.50 \pm 3.92$ \\
CPK (I.U./l) & $312 \pm 39.5$ & $175 \pm 16.3$
\end{tabular}

This cholesterol lowering property has not been found previously in any marine microalga, although this effect has been observed with freshwater mi.:roargae. IV'here the hypocholesterolemic effect increased as the percentage of microalga in diet was increased $(6,7,8.9)$.

\section{Acknowledgements}

This work was supported by a grant from Fondo de Investigaciones Sanitarias de la Seguridad Social FISSS), Ministerio de Sanidad y Consumo (No 86/1157). Thanks are due to M.A. García Saavedra, A. Barrero Vázquez and A. Fernandez Jover for their technical help.

\section{References}

(1) Vahouny, G. V. (1985) in: Drugs Affecting Lipid Metabolism VIII (Kritchevsky, D. , Holmes, W. L., Palleti, R., eds.), Plenum Publishing Corporation , pp. 265-279.

(2) Endo, A., Kuroda, M., Tsujita, T. (1979) J. Antibiot. 29, 1346-1348.

(3) Endo, A. (1979) J. Antibiot. 32, 852-854. 
(4) Alberst-Schonberg, G., Joshua, H., Lopez, M. B., Hensens, O. D., Springer, J. P., Chen, I., Ostrove, S., Hoffman, C. H., Alberts, A. W., Patchett, A. A. (1981) J. Antibiot. 34(5), 507-512.

(5) Udall, J. N., Lo, C. W., Young, V. R., Scrimshaw, N. S., (1984) Am. J. Clin. Nutr. 40, 285292.

(6) Anusuya-Devi, M., Venkataraman, L. V., Rajasekaran, T. (1979) Nutr. Rep. Int. 20, 83-90.

(7) Becker, E. W., Venkataraman, L. V. (1982) Biotechnology and Explotation of Algae-The Indian Approach, Ageocy for Technical Cooperation (GTZ), D-6236 Eschlorm, Federal Republic of Germany, $216 \mathrm{pp}$.

(8) Rolle, I., Pabst, W. (1980) Nutr. Metab. 24, 302-313.

(9) Venkataraman, L. V. (1983) Blue-green Alga Spirulina, Department of Science and Technology, India, CFTRI Press, Mysore, $100 \mathrm{pp}$.

(10) Fabregas, J., Herrero, C., Abalde, J. , Liafio, R., Cabezas, B. (1986) Aquaculture 53,187199.

(11) AOAC (1980) Official Methods of Analysis, 13th Ed, Association of Official Agricultural Chemist, Washington D. C.

(12) LASA (1969) Dietary standards for laboratory rats and mice, London, Laboratory Animals Ltd.

(13) Weick, H., Drepper, K. (1970) Z. Versuchstierkunde 12, 379.

(14) Fabregas J., Herrero, C. (1985) Appl. Microbiol. Biotechnol. 23, 110-113

(IS) Fabregas, J., Herrero, C. (1986) Aquaculture 51, 237-243.

(16) Lane-Petter, W., Pearson, A. E. G. (1971) Laboratory Animal Principles and Practise. Academic Press, London, NY, pp. 141-163.

(17) Quartenam, J. (1967) Husbandry of Laboratory Animals, (M. Conalty, ed.), Academic Press, New York, pp. 1115. 